\title{
Implementasi Algoritma K-Medoids dan K-Means untuk Pengelompokkan Wilayah Sebaran Cacat pada Anak
}

\author{
Dini Marlina ${ }^{1}$, Nurelina Fauzer Putri ${ }^{2}$, Andri Fernando ${ }^{3}$, Aditya Ramadhan ${ }^{4}$ \\ 1,2,3,4 Program Studi Sistem Informasi, Fakultas Sains dan Teknologi \\ Jl. H.R. Soebrantas no. 155 KM. 18 Simpang Baru, Pekanbaru 28293 \\ 1dinimarlinacosco@gmail.com, ${ }^{2}$ fauz3rlina@gmail.com, ${ }^{3}$ andrifernando61@gmail.com, ${ }^{4}$ adhitkha@gmail.com
}

\begin{abstract}
Abstrak - Usia dibawah 18 tahun merupakan usia yang baik dalam pertumbuhan dan perkembangan fisik dan mental pada seseorang. Pertumbuhan dan perkembangan yang baik akan menjadi modal bagi kelangsungan anak sebagai generasi penerus yang baik. Namun, seorang anak yang dilahirkan dalam keadaan cacat fisik yang berat beresiko untuk mengalami stress dan hambatan penyesuaian. Dinas Sosial Provinsi Riau mengaku fasilitas yang diberikan kepada penyandang cacat masih rendah. Selain itu, angka penyandang cacat di Provinsi Riau lebih dari 11 ribu tersebar di seluruh Kabupaten/ Kota di Provinsi Riau. K-Medoids mampu melakukan pengelompokan pada data sebaran anak cacat yang ada pada Provinsi Riau. Klaster yang dihasilkan pada penelitian ini adalah berjumlah tiga klaster. Validitas yang digunakan pada penelitian ini adalah validitas Silhoutte Coefficient Adapun nilai validitas yang dihasilkan pada algoritma K-Medoids adalah sebesar 0.5009. Sedangkan nilai validitas yang dihasilkan pada algoritma K-Means adalah 0.1443 . Hal ini menunjukkan bahwa algoritma K-Medoids lebih baik dalam melakukan pengelompokan pada data sebaran Anak Cacat dibandingkan dengan algoritma KMeans.
\end{abstract}

Kata Kunci - Cacat, Clustering, Data Mining, KMedoids, Validasi

\section{PENDAHULUAN}

Usia dibawah 18 tahun merupakan usia yang baik dalam pertumbuhan dan perkembangan fisik dan mental pada seseorang. Pertumbuhan dan perkembangan yang baik akan menjadi modal bagi kelangsungan anak sebagai generasi penerus yang baik. Namun, seorang anak yang dilahirkan dalam keadaan cacat fisik yang berat beresiko untuk mengalami stress dan hambatan penyesuaian. Kecacatan sering mengakibatkan masalah-masalah sosial, seperti penolakan oleh lingkungan sosialnya, kesulitan dalam membina hubungan sosial, dan sikap over-proteksi dari orang lain[1].

Penyandang cacat adalah setiap orang yang mempunyai kelainan fisik dan/ atau mental, yang dapat mengganggu atau merupakan rintangan dan hambatan baginya untuk melakukan secara selayaknya[2].Dinas Sosial Provinsi Riau mengaku fasilitas yang diberikan kepada penyandang cacat masih rendah. Selain itu, angka penyandang cacat di Provinsi Riau lebih dari 11 ribu tersebar di seluruh Kabupaten/ Kota di Provinsi Riau [3]

Dampak penolakan lingkungan dan masalahmasalah sosial lainnya yang menimpa penyandang cacat mendorong berbagai pihak untuk melakukan pencegahan secara dini. Mengingat pertumbuhan dan perkembangan anak dapat terganggu saat usia dibawah 18 tahun. Salah satu langkah awal yang dapat dilakukan yaitu dengan memprakirakan wilayah-wilayah penyandang cacat yang tinggi. Pemanfaatan data sebaran anak cacat dapat dilakukan untuk proses pengelompokan sesuai dengan informasi yang dimiliki oleh data, sehingga dapat diketahui wilayah mana yang memiliki sebaran cacat yang tinggi. Proses pengelompokkan dapat dilakukan dengan mengimplementasikan metode clustering.

Ada beberapa teknik untuk melakukan klasterisasi, diantaranya $K$-Means, $K$-Medoids dan lainnya. Teknik K-Means diperkenalkan oleh MacQueenm (1967), sedangkan teknik K-Medoids (Partitioning Around Medoids) diperkenalkan oleh Kaufman dan Rousseeuw (1990)[4].Berdasarkan penelitian yang dilakukan oleh (Aishwaya) didapati kesimpulan bahwaalgoritmaK-Means efisien untuk kumpulan data yang lebih kecil dan $K$-Medoids nampaknya berperforma lebih baik untuk dataset besar[5].

Berdasarkan permasalahan dan paparan penelitian sebelumnya, penulis membuat sebuah penelitian berjudul "Implementasi Algoritma $K$ Medoids untuk Pengelompokkan Wilayah Sebaran Cacat pada Anak". Penelitian ini dapat menjadi sebuah solusi agar memudahkan dalam mengetahui wilayah-wilayah yang memiliki tingkat anak cacat yang tinggi nsehingga dapat dilakukan penanggulangan secara dini.

\section{METODE PENELITIAN}

Metodologi penelitian menjelaskan langkahlangkah yang akan digunakan serta perancangan dalam melakukan implementasi metode $K$-Medoids 
clustering untuk pengelompokan data wilayah sebaran cacar berdasarkan jumlah penderita dibawah 18 tahun. Berikut adalah metodologi penelitian pada penelitian ini:

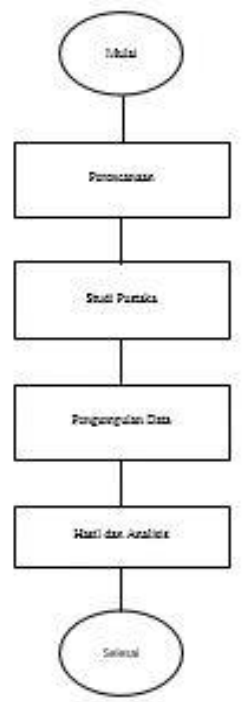

Gambar 1. Metodologi penelitian

\section{Cacat}

Cacat adalah setiap orang yang memiliki kelainan fisik dan/atau mental, yang dapat mengganggu atau merupakan rintangan dan hambatan baginya untuk melakukan secara selayaknya, yang terdiri dari[6]:

a. Penyandang cacat fisik.

b. Penyandanga ccat mental.

c. Penyandang cacat fisik dan mental.

\section{Knowledge Discovery in Database (KDD)}

Istilah data mining dan knowledge discovery in database (KDD) sering kali digunakan secara bergantian untuk menjelaskan proses penggalian informasi tersembunyi dalam suatu basis data yang besar. Sebenarnya kedua istilah tersebut memiliki konsep yang berbeda, tetapi berkaitan satu sama lain. Salah satu tahapan dalam keseluruhan proses KDD adalah data mining. Proses KDD secara garis besar dapat dijelaskan sebagai berikut:[7]

1. Data Selection, pemilihan (seleksi) data dari sekumpulan dataoperasional perlu dilakukan sebelum tahappenggalian informasi dalam KDD dimulai. Data hasilseleksi yang akan digunakan untuk proses data mining disimpan dalam suatu berkas, terpisah daribasis data operasional.

2. Pre-processing / Cleaning, sebelum proses data mining dapat dilaksanakan, perlu dilakukan proses pembersihan pada data yangmenjadi fokus KDD. Proses pembersihan mencakupantara lain membuang duplikasi data, memeriksa data yang inkosisten, dan memperbaiki kesalahan pada data, seperti kesalahan cetak (tipografi).
3. Transformation Coding adalah transformasi pada data yang telahdipilih, sehingga data tersebut sesuai untuk proses data mining. Proses coding dalam KDD merupakan proses kreatif dan sangat tergantung pada jenis ataupola informasi yang akan dicari dalam basis data.

4. Data mining, data mining adalah proses mencari pola atauinformasi menarik dalam data terpilih denganmenggunakan teknik atau metode tertentu. Teknik, metode, atau algoritma dalam data mining sangatbervariasi. Pemilihan metode atau algoritma yangtepat sangat bergantung pada tujuan dan proses KDDsecara keseluruhan.

5. Interpretation / Evaluation, pola informasi yang dihasilkan dari proses dataminingperlu ditampilkan dalam bentuk yang mudah dimengerti oleh pihak yang berkepentingan. Tahapini merupakan bagian dari proses KDD yang disebutinterpretation. Tahap ini mencakup pemeriksaanapakah pola atau informasi yang ditemukanbertentangan dengan fakta atau hipotesis yang ada sebelumnya

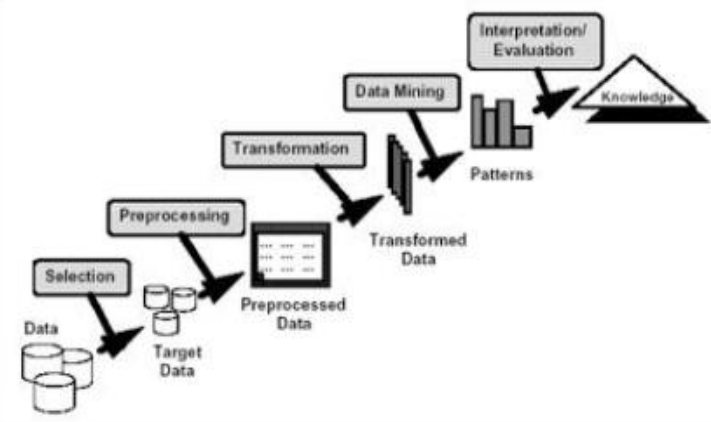

Gambar 2. Proses Data Mining Dalam Penemuan Pengetahuan Dalam Database [8]

\section{Clustering}

Clustering merupakan suatu proses pengelompokan data, observasi, atau mengelompokan kelas yang memiliki kesamaan objek [9]. Berbeda dengan proses klasifikasi, clustering tidak mempunyai target variable dalam melakukan. Clustering sering dilakukan sebagai langkah awal dalam proses data mining. Terdapat banyak algoritma klastering yang telah digunakan oleh peneliti sebelumnya seperti $K$-Means, Improved K-Means, K-Medoids (PAM), Fuzzy C-Means, DBSCAN, CLARANS dan Fuzzy Substractive.

Clustering telah digunakan secara luas dan pentingnya pengelompokan tumbuh dengan cepat dikarenakan jumlah data yang berhubungan dengan eksponen aljabar dalam kecepatan pengolahan komputer sangat banyak[10]. Algoritma clustering berfungsi untuk mengelompokan data sesuaidengan karakteristik dan mengukur jarak kemiripan antar data dalam satu kelompok walaupun setiap 
algortimaclustering memiliki kelebihan dan kekurangan masing-masing.

\section{Normalisasi data}

Normalisasi adalah proses transformasi untuk merubah nilai data. Normalisasi digunakan untuk menyamakan skala atribut data kedalam range yang spesifik yang lebih kecil seperti - 1 sampai 1 atau 0 sampai 1. min-Max Normalization merupakan teknik normalisasi dengan melakukan transformasi linear pada atribut data asli untuk menghasilkan range nilai yang sama [11]. Min-Max Normalization memetakan sebuah value v dari atribut A menjadi v' kedalam range [new_minA, new_MaxA] dengan persamaan 1 .

$$
\begin{aligned}
& v^{\prime}=\frac{v-\min _{A}}{\max _{A}-\min _{A}}\left(\text { new } \max _{A}-\text { new } \min _{A}\right)+ \\
& n e w_{\min A}
\end{aligned}
$$

\section{K-Medoids}

K-Medoids adalah salah satu metode partisi, karena menggunakan objek yang paling terpusat (medoids) di cluster menjadi pusat cluster dari nilai rata-rata objek dalam sebuah cluster. Metode Kmedoids lebih cocok untuk mengelompokkan data dibandingkan metode $K$-Means [12].

Adapun alur algoritma dari K-Medoid adalah sebagai berikut:

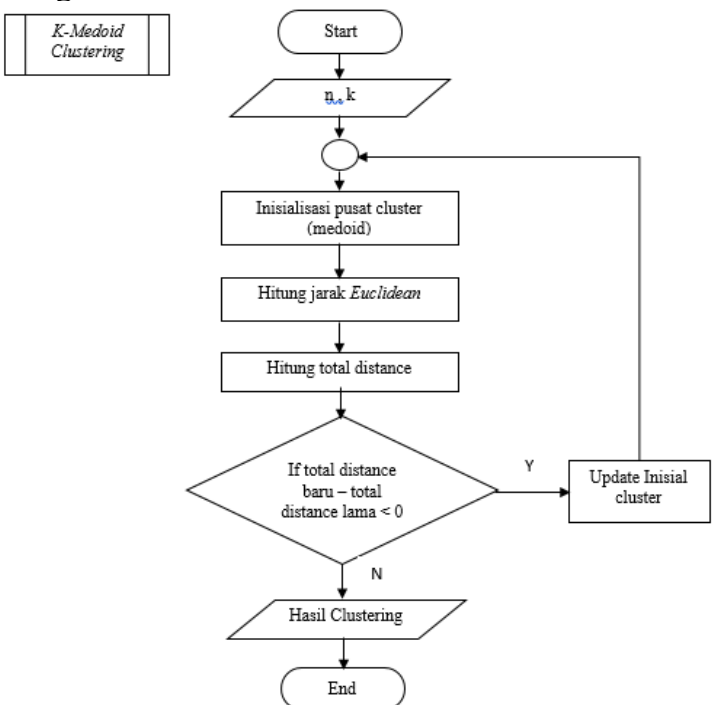

Gambar 3. Alur algoritma K-Medoids

Langkah-langkah algoritma $K$-Medoids:

1. Inisialisasi pusat cluster sebanyak $k$ (jumlah cluster)

2. Alokasikan setiap data (objek) ke cluster terdekat menggunakan persamaan ukuran jarak Euclidian Distance dengan persamaan:

$$
d(x, y)=\sqrt{\sum_{i=1}^{n}\left(x_{i}-y_{i}\right)^{2}}
$$

3. Pilih secara acak objek pada masing-masing cluster sebagai kandidat medoids baru.
4. Hitung jarak setiap objek yang berada pada masing-masing cluster dengan kandidat medoids baru.

5. Hitung total simpangan $(S)$ dengan menghitung nilai total distance baru - total distance lama. Jika $S<0$, maka tukar objek dengan data cluster untuk membentuk sekumpulan $k$ objek baru sebagai medoid.

6. Ulangi langkah 3 sampai 5 hingga tidak terjadi perubahan medoids, sehingga didapatkan cluster beserta anggota clustermasing-masing.

\section{K-Means}

K-means adalah algoritma untuk pelatihan unsupervise, pertama kali dipublikasikan oleh Stuart Loyd pada tahun 1984 dan merupakan algoritma clustering yang banyak digunakan. Algoritmanya cukup mudah untuk diimplementasi dan dijalankan, relatif cepat, mudah disesuaikan dan banyak digunakan. Prinsip utama dari teknik ini adalah menyusun kbuah partisi/pusat (centroid)/ rata-rata (mean) dari sekumpulan data. Algoritma K-means dimulai dengan pembentukan partisi klaster di awal kemudian secara iteratif partisi klaster ini diperbaiki hingga tidak terjadi perubahan yang signifikan pada partisi klaster [13].

Adapun alur algoritma dari K-Means adalah sebagai berikut:

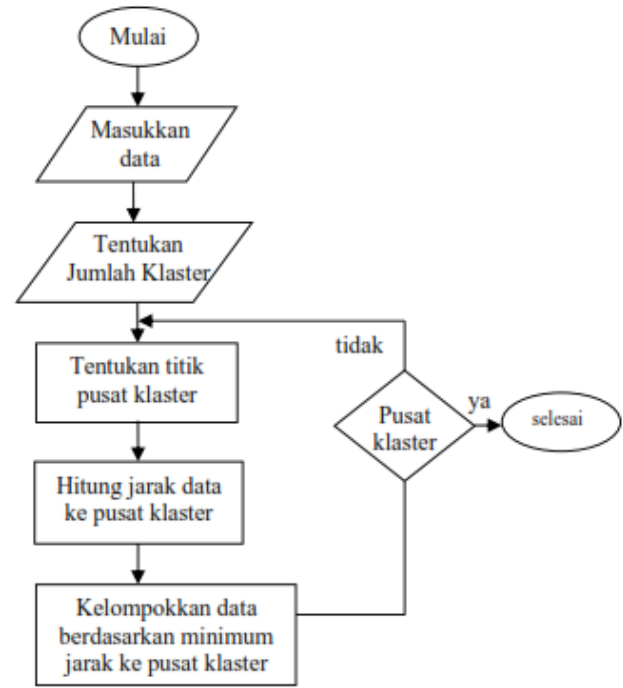

Gambar 4. Alur algoritma K-Means[16]

Data clustering menggunakan algoritma $K$ Means secara umum dilakukan dengan algoritma dasar sebagai berikut: [14]

1. Tentukan jumlah cluster

2. Alokasikan data ke dalam cluster secara random

3. Hitung centroid/ rata-rata dari data yang ada di masing-masing cluster

4. Alokasikan masing-masing data ke centroid/ rata-rata terdekat 
5. Kembali ke Step 3, apabila masih ada data yang berpindah cluster atau apabila perubahan nilai centroid, ada yang di atas nilai threshold yang ditentukan atau apabila perubahan nilai pada objective function yang digunakan di atas nilai threshold yang ditentukan

\section{Silhoutte Coefficient Index (SI)}

Silhoutte Coefficient Index adalah salah satu metode analisa untuk mendapatkan nilai validasi pada sebuah metode clustering. Hasil perhitungan nilai silhouette coefficient dapat bervariasi antara -1 hingga 1. Jika $s i=1$ berarti objek i sudah berada dalam cluster yang tepat. Jika nilai $s i=0$ maka objek i berada di antara dua cluster sehingga objek tersebut tidak jelas harus dimasukan ke dalam cluster A atau cluster B. Akan tetapi, jika si = -1 artinya struktur cluster yang dihasilkan overlapping, sehingga objek i lebih tepat dimasukan ke dalam cluster yang lain[15].

\section{HASIL DAN PEMBAHASAN}

Pada bagian ini akan dijelaskan bagaimana mengimplementasikan algoritma K-Medoidss pada data Sebaran Anak Cacat yang terdapat pada Provinsi Riau. Sebelum dilakukan perhitungan, Hasil dari metode K-Medoids syaitu mengetahui pengelompokan desa berdasarkan jumlah penyandang cacat. Adapun atribut yang digunakan terdapat pada Tabel 1 .

Tabel 1. Atribut yang Digunakan

\begin{tabular}{lc}
\hline \multicolumn{1}{c}{ Atribut } & Inisialisasi \\
\hline Desa & Desa \\
Tidak cacat $<5 \%$ & $\mathrm{X} 1$ \\
Tidak cacat $6 \%-10 \%$ & $\mathrm{X} 2$ \\
Tidak cacat $11 \%-20 \%$ & $\mathrm{X} 3$ \\
Tidak cacat $21 \%-30 \%$ & $\mathrm{X} 4$ \\
Tidak cacat $31 \%-40 \%$ & $\mathrm{X} 5$ \\
Cacat (Semua Fisik) & $\mathrm{X} 6$ \\
Tuna Daksa & $\mathrm{X} 7$ \\
Tuna Netra & $\mathrm{X} 8$ \\
Tuna Rungu & $\mathrm{X} 9$ \\
Tuna Wicara & $\mathrm{X} 10$ \\
Cacat Mental & $\mathrm{X} 11$ \\
Mantan Penderita Gangguan Jiwa & $\mathrm{X} 12$ \\
\hline
\end{tabular}

Data yang digunakan dalam penelitian ini adalah data Sebaran Anak Cacat yang diunduh dari data.go.id. Adapun data yang digunakan adalah data desa yang berada pada Provinsi Riau. Data yang diolah dapat dilihat pada Tabel 2 .

Sebelum dilakukan pengolahan data menggunakan Algoritma K-Medoids, lakukan proses normalisasi. Adapun hasil normalisasi data sebaran cacat dapat dilihat pada Tabel 3.

Percobaan perhitungan merujuk pada lima atribut jumlah penyandang cacat setiap desa, yaitu Tidak cacat $<5 \%$, Tidak cacat $6 \%-10 \%$, Tidak cacat
$11 \%-20 \%$, Tidak cacat $21 \%-30 \%$, Tidak cacat $31 \%$ $40 \%$ dan cacat (Semua Fisik).

\section{Perhitungan $\mathbf{K}$-Medoids}

Algoritma K-Medoids dimulai pada penentuan awal pusat klaster dengan memilih secara acak di antara objek yang ada pada dataset. Jumlah objek yang dipilih sesuai dengan jumlah cluster yang diinginkan, hal ini dikarenakan objek yang terpiih akan merepresentasikan pusat dari cluster sebagai medoids, untuk kasus ini akan dipilih tiga buah objek sebagai medoids awal. Medoids awal dapat dilihat pada Tabel 4.

Langkah selanjutnya adalah menghitung jarak setiap seluruh objek non-medoids. Objek dengan jarak terdekat dengan masing-masing medoids akan bergabung dengan medoids tersebut. Objek yang paling dekat dengan medoids 1 (C1) dapat dilihat pada Tabel 5. Objek yang paling dekat dengan medoids 2 (C2) dapat dilihat pada Tabel 6. Objek yang paling dekat dengan medoids 3 (C3) dapat dilihat pada Tabel 7.

Selanjutnya mencari nilai cost dengan melakukan perhitungan jarak antara objek dengan setiap medoids dengan menggunakan metoda Eucleadean Distance. Adapun rumus Eucleadian Distance adalah sebagai berikut:

$d(C 1,02)$

$=\sqrt{(0.0018-0.0108)^{2}+(0.0051-0.0255)^{2}+\cdots+(0.0581-0.0000)^{2}}$ $=0.0492$

Lakukan perhitungan jarak pada seluruh data yang mendekati medoids 1 dan sehingga didapatkan jumlah cost medoids 1 ke objek data yang mendekati medoids 1 .

$\sum S(C 1, O i)=d(C 1, O 2)+d(C 1, O 4)+\cdots+d(C 1,01636)$
$\sum S(C 1, O i)=0.0492+0.0857+\cdots+0.0651=32.1567$

Lakukan perhitungan jarak pada seluruh data yang mendekati medoids lainnya. Adapun jumlah cost pada medoidss 2 dan 3 yaitu:

$\sum S(C 2, O i)=0.1047+0.1390+\cdots+0.0774=26.5401$
$\sum S(C 2, O i)=0.0751+0.1431+\cdots+0.4091=119.6672$

Setelah dihitung jumlah cost pada data masing-masing medoids, maka didapatkan jumlah seluruh cost yang ada pada percobaan pertama.

$\sum S(C i, O i)=32.1567+26.5401+119.6672=178.3640$

Setelah nilai cost pada percobaan pertama didapatkan, lakukan hal yang sama pada percobaan kedua dengan melakukan pemilihan medoids 
kembali secara acak, lakukan perubahan medoids yang ada pada data. Setelah menentukan medoids, hitunglah jarak setiap seluruh objek non-medoidss. Objek dengan jarak terdekat dengan masing-masing medoids akan bergabung dengan medoids tersebut. Kemudian mencari nilai cost dengan melakukan perhitungan jarak antara objek dengan setiap medoids dengan menggunakan metoda Eucleadean Distance. Sehingga pada percobaan kedua didapatkan nilai jumlah cost sebagai berikut:

$\sum S(C i, O i)=49.0599+7.9079+185.6273=185.6273$

Perhitungan yang dihasilkan dari dua kali percobaan dapat dilihat pada Tabel 8 . Tabel 8 menjelaskan bahwa terdapat perubahan jumlah cost dari 178.3640 menjadi 185.6273 maka nilai $\sum \mathrm{S}(\mathrm{Ci}, \mathrm{Oi})$ pertama $<\sum \mathrm{S}(\mathrm{Ci}, \mathrm{Oi})$ kedua, oleh karena itu algoritma berhenti pada tahap ini dan tidak ada perubahan susunan cluster pada percobaan pertama.

Data pada klaster ke 1 dapat dilihat pada Tabel 9. Jumlah data yang terdapat pada Klaster 1 adalah 601 data. Pola yang terbentuk pada klaster 1 adalah jumlah tidak cacat $<5 \%$ antara 0 hingga 64 . Sedangkan untuk jumlah cacat (semua fisik) antara 0-5. Sementara jumlah penyandang Tuna Daksa, Tuna Netra, Tuna Rungu, Tuna Wicara, dan Cacat Mental masing-masing adalah 3, 2, 1, 2, dan 3.

Data pada klaster kedua dapat dilihat pada Tabel 10. Jumlah data yang terdapat pada klaster kedua adalah 352 data. Pola yang terbentuk pada klaster 2 adalah jumlah tidak cacat $<5 \%$ antara 0 hingga 164. Sedangkan untuk jumlah cacat (semua fisik) antara 0-8. Sementara jumlah penyandang Tuna Daksa, Tuna Netra, Tuna Rungu, Tuna Wicara, dan Cacat Mental masing-masing adalah 7, 1, 3, 2, dan 3 .

Data pada klaster ketiga dapat dilihat pada Tabel 11. Jumlah data yang terdapat pada klaster ketiga adalah 698 data. Pola yang terbentuk pada klaster 3 adalah jumlah tidak cacat $<5 \%$ antara 0 hingga 1116. Sedangkan untuk jumlah cacat (semua fisik) antara 0-15. Sementara jumlah penyandang Tuna Daksa, Tuna Netra, Tuna Rungu, Tuna Wicara, dan Cacat Mental masing-masing adalah 7, 5, 3, 4, dan 5 .

Grafik hasil klaster pada data sebaran cacat pada anak dapat dilihat pada Gambar 5.

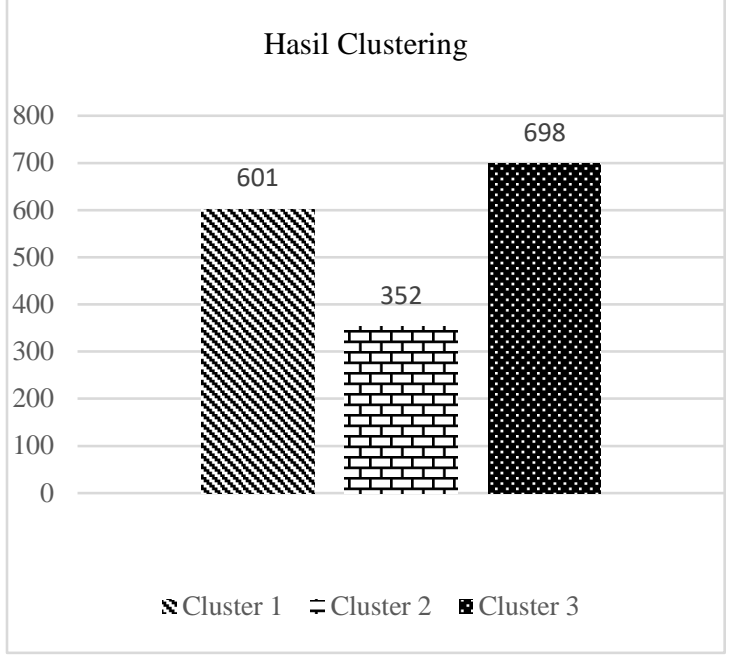

Gambar 5. hasil klaster data sebaran cacat pada anak

\section{Perhitungan K-Means}

Perhitungan juga dilakukan pada Algoritma $K$-Means untuk mengetahui perbedaan pola yang terentuk. Dalam algoritma K-Means, cluster 1 yang terbentuk dapat dilihat pada Tabel 12, cluster 2 yang terbentuk dapat dilihat pada Tabel 13, cluster 3 yang terbentuk dapat dilihat pada Tabel 14

\section{Validasi K-Medoids dan K-Means}

Perhitungan Silhoutte Coefficient Index (SI) digunakan untuk mengetahui kinerja tiap algoritma clustering. Adapun hasil perhitungan validasi Silhoutte pada metode $K$-Medoids dapat dilihat pada Tabel 15.

Rata-rata Silhoutte Coefficient pada $K$ Medoids adalah 0.5009, ini menunjukkan bahwa metode K-Medoids cukup baik dalam melakukan Pengelompokan pada data sebaran cacat pada Anak di wilayah Provinsi Riau.

Sedangkan pada Algoritma K-Means, nilai yang dihasilkan pada validasi Silhoutte Coefficient dapat dilihat pada Tabel 16.

Rata-rata Silhoutte Coefficient pada K-Means adalah 0.1443 , ini menunjukkan bahwa metode $K$ Means cukup baik. Namun jika dibandingkan dengan algoritma $K$-Medoids, algoritma $K$-Means mempunyai nilai validitas yang lebih rendah dalam melakukan pengelompokan pada data sebaran cacat pada anak di wilayah Provinsi Riau.

Tabel 2. Data yang Digunakan

\begin{tabular}{clrrrrrrrrrrcc}
\hline No & \multicolumn{1}{c}{ Desa } & X1 & X2 & X3 & X4 & X5 & X6 & X7 & X8 & X9 & X10 & X11 & X12 \\
\hline 1 & Sungai Besar & 51 & 86 & 94 & 70 & 17 & 3 & 1 & 0 & 0 & 1 & 0 & 0 \\
2 & Ibul & 12 & 20 & 34 & 34 & 5 & 0 & 0 & 0 & 0 & 0 & 0 & 0 \\
3 & Pangkalan & 49 & 56 & 68 & 47 & 2 & 2 & 0 & 0 & 1 & 0 & 0 & 0 \\
4 & Muara Petai & 35 & 17 & 35 & 21 & 4 & 1 & 0 & 0 & 0 & 0 & 1 & 0 \\
5 & Pantai & 22 & 30 & 39 & 14 & 7 & 0 & 0 & 0 & 0 & 0 & 0 & 0 \\
$\ldots$ & $\ldots$ & $\ldots$ & $\ldots$ & $\ldots$ & $\ldots$ & $\ldots$ & $\ldots$ & $\ldots$ & $\ldots$ & $\ldots$ & $\ldots$ & $\ldots$ & $\ldots$ \\
1656 & Bintan & 25 & 14 & 148 & 238 & 156 & 4 & 1 & 0 & 0 & 0 & 3 & 0 \\
\hline
\end{tabular}


Tabel 3. Medoids secara acak

\begin{tabular}{|c|c|c|c|c|c|c|c|c|c|c|}
\hline No & Nama Desa & $\mathrm{x} 1$ & $\mathrm{x} 2$ & $\mathrm{x} 3$ & $\mathrm{x} 4$ & $\mathrm{x} 5$ & $\mathrm{x} 6$ & $\mathrm{x} 7$ & $\ldots$ & $\mathrm{x} 12$ \\
\hline 1 & Sungai Besar & 0.0457 & 0.1096 & 0.0421 & 0.0390 & 0.0494 & 0.2000 & 0.1429 & $\ldots$ & 0.0000 \\
\hline 2 & Ibul & 0.0108 & 0.0255 & 0.0152 & 0.0189 & 0.0145 & 0.0000 & 0.0000 & $\ldots$ & 0.0000 \\
\hline 3 & Pangkalan & 0.0439 & 0.0713 & 0.0305 & 0.0262 & 0.0058 & 0.1333 & 0.0000 & $\ldots$ & 0.0000 \\
\hline 4 & Muara Petai & 0.0314 & 0.0217 & 0.0157 & 0.0117 & 0.0116 & 0.0667 & 0.0000 & $\ldots$ & 0.0000 \\
\hline 5 & Pantai & 0.0197 & 0.0382 & 0.0175 & 0.0078 & 0.0203 & 0.0000 & 0.0000 & $\ldots$ & 0.0000 \\
\hline$\ldots$ & $\ldots$ & $\ldots$ & $\ldots$ & $\cdots$ & $\ldots$ & $\cdots$ & $\ldots$ & $\ldots$ & $\cdots$ & $\cdots$ \\
\hline 1656 & Bintan & 0.0224 & 0.0178 & 0.0663 & 0.1324 & 0.4535 & 0.2267 & 0.1429 & $\ldots$ & $\ldots$ \\
\hline
\end{tabular}

Tabel 4. Medoids secara acak

\begin{tabular}{|c|c|c|c|c|c|c|c|c|c|c|}
\hline No & Nama Desa & $\mathrm{X} 1$ & $\mathrm{X} 2$ & $\mathrm{X} 3$ & $\mathrm{X} 4$ & $\mathrm{X5}$ & X6 & $\mathrm{X} 7$ & $\ldots$ & $\mathrm{X} 12$ \\
\hline 411 & Kuala Keritang & 0.0018 & 0.0051 & 0.0166 & 0.0234 & 0.0581 & 0.0000 & 0.0000 & $\cdots$ & 0.0000 \\
\hline 828 & Sungai Tengah & 0.0054 & 0.0204 & 0.0143 & 0.0256 & 0.0872 & 0.0000 & 0.0000 & $\ldots$ & 0.0000 \\
\hline 1242 & Harapan Baru & 0.0573 & 0.0471 & 0.0708 & 0.0668 & 0.0523 & 0.0667 & 0.0000 & $\ldots$ & 0.0000 \\
\hline
\end{tabular}

Tabel 5. Objek yang mendekati medoids 1

\begin{tabular}{|c|c|c|c|c|c|c|c|c|c|c|}
\hline No & Nama Desa & $\mathrm{x} 1$ & $\mathrm{x} 2$ & $\mathrm{x} 3$ & $\mathrm{x} 4$ & $\mathrm{x} 5$ & $\mathrm{x} 6$ & $\mathrm{x} 7$ & $\ldots$ & $\mathrm{x} 12$ \\
\hline 2 & Ibul & 0.0108 & 0.0255 & 0.0152 & 0.0189 & 0.0145 & 0.0000 & 0.0000 & $\ldots$ & 0.0000 \\
\hline 4 & Muara Petai & 0.0314 & 0.0217 & 0.0157 & 0.0117 & 0.0116 & 0.0667 & 0.0000 & $\ldots$ & 0.0000 \\
\hline 5 & Pantai & 0.0197 & 0.0382 & 0.0175 & 0.0078 & 0.0203 & 0.0000 & 0.0000 & $\ldots$ & 0.0000 \\
\hline 8 & Koto Cengar & 0.0251 & 0.0229 & 0.0076 & 0.0061 & 0.0000 & 0.0000 & 0.0000 & $\ldots$ & 0.0000 \\
\hline$\ldots$ & $\ldots$ & $\ldots$ & $\ldots$ & $\ldots$ & $\ldots$ & $\ldots$ & 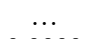 & 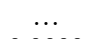 & $\ldots$ & \\
\hline 1636 & Batu Teritip & 0.0152 & 0.0038 & 0.0282 & 0.0000 & 0.0000 & 0.0000 & 0.0000 & $\ldots$ & 0.0000 \\
\hline
\end{tabular}

Tabel 6. Objek yang mendekati medoids 2

\begin{tabular}{clcccccccccc}
\hline No & \multicolumn{1}{c}{ Nama Desa } & $\mathrm{x} 1$ & $\mathrm{x} 2$ & $\mathrm{x} 3$ & $\mathrm{x} 4$ & $\mathrm{x} 5$ & $\mathrm{x} 6$ & $\mathrm{x} 7$ & $\ldots$ & $\mathrm{x} 12$ \\
\hline 3 & Pangkalan & 0.0439 & 0.0713 & 0.0305 & 0.0262 & 0.0058 & 0.1333 & 0.0000 & $\ldots$ & \\
6 & Air Buluh & 0.0968 & 0.0777 & 0.0125 & 0.0017 & 0.0029 & 0.3333 & 0.2857 & $\ldots$ & 0.0000 \\
7 & Lubuk Ramo & 0.0439 & 0.0331 & 0.0296 & 0.0195 & 0.0174 & 0.0000 & 0.0000 & $\ldots$ & 0.0000 \\
9 & Seberang Cengar & 0.0367 & 0.0522 & 0.0219 & 0.0128 & 0.0116 & 0.0667 & 0.0000 & $\ldots$ & 0.0000 \\
$\ldots$ & $\ldots$ & $\ldots$ & $\ldots$ & $\ldots$ & $\ldots$ & $\ldots$ & $\ldots$ & $\ldots$ & $\ldots$ & $\ldots$ & $\ldots$ \\
1623 & Tebing Tinggi Okura & 0.0421 & 0.0433 & 0.0511 & 0.0306 & 0.0349 & 0.2667 & 0.1429 & $\ldots$ & 0.0000 \\
\hline
\end{tabular}

Tabel 7. Objek yang mendekati medoids 3

\begin{tabular}{|c|c|c|c|c|c|c|c|c|c|c|}
\hline No & Nama Desa & $\mathrm{x} 1$ & $\mathrm{x} 2$ & $\mathrm{x} 3$ & $\mathrm{x} 4$ & $\times 5$ & $\mathrm{x6}$ & $\mathrm{x} 7$ & $\mathrm{x} 8$ & $\mathrm{x} 12$ \\
\hline 1 & Sungai Besar & 0.0457 & 0.1096 & 0.0421 & 0.0390 & 0.0494 & 0.2000 & 0.1429 & 0.0000 & 0.0000 \\
\hline 57 & Muara Lembu & 0.1308 & 0.1516 & 0.0287 & 0.0273 & 0.0233 & 0.2667 & 0.4286 & 0.0000 & 0.0000 \\
\hline 66 & Sungai Kuning & 0.1263 & 0.1006 & 0.0143 & 0.0161 & 0.0000 & 0.0000 & 0.0000 & 0.0000 & 0.0000 \\
\hline 69 & Sungai Buluh & 0.1102 & 0.1210 & 0.0578 & 0.0356 & 0.0436 & 0.1333 & 0.1429 & 0.0000 & 0.0000 \\
\hline$\ldots$ & $\ldots$ & $\ldots$ & $\ldots$ & $\ldots$ & $\ldots$ & $\ldots$ & 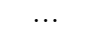 & . & $\ldots$ & $\ldots$ \\
\hline 1656 & Bintan & 0.0224 & 0.0178 & 0.0663 & 0.1324 & 0.4535 & 0.2667 & 0.1429 & & 0.0000 \\
\hline
\end{tabular}

Tabel 8. Hasil cost pada Kedua Percobaan

$\begin{array}{lc}\text { Cost } & \text { Hasil } \\ \sum S(\text { Ci, Oi }) \text { pertama } & 178.3640 \\ \sum S(\text { Ci,Oi }) \text { kedua } & 185.6273\end{array}$

Tabel 9. Data pada Klaster 1

\begin{tabular}{clccccccccc}
\hline No & \multicolumn{1}{c}{ Nama Desa } & $\mathrm{x} 1$ & $\mathrm{x} 2$ & $\mathrm{x} 3$ & $\mathrm{x} 4$ & $\mathrm{x} 5$ & $\mathrm{x} 6$ & $\mathrm{x} 7$ & $\ldots$ & $\mathrm{x} 12$ \\
\hline 2 & Ibul & 0.0108 & 0.0255 & 0.0152 & 0.0189 & 0.0145 & 0.0000 & 0.0000 & $\ldots$ & 0.0000 \\
4 & Muara Petai & 0.0314 & 0.0217 & 0.0157 & 0.0117 & 0.0116 & 0.0667 & 0.0000 & $\ldots$ & 0.0000 \\
5 & Pantai & 0.0197 & 0.0382 & 0.0175 & 0.0078 & 0.0203 & 0.0000 & 0.0000 & $\ldots$ & 0.0000 \\
8 & Koto Cengar & 0.0251 & 0.0229 & 0.0076 & 0.0061 & 0.0000 & 0.0000 & 0.0000 & $\ldots$ & 0.0000 \\
$\ldots$ & $\ldots$ & $\ldots$ & $\ldots$ & $\ldots$ & $\ldots$ & $\ldots$ & $\ldots$ & $\ldots$ & $\ldots$ & $\ldots$ \\
1636 & Batu Teritip & 0.0152 & 0.0038 & 0.0282 & 0.0000 & 0.0000 & 0.0000 & 0.0000 & $\ldots$ & 0.0000 \\
\hline
\end{tabular}

Tabel 10. Data pada Klaster 2

\begin{tabular}{|c|c|c|c|c|c|c|c|c|c|c|}
\hline No & Nama Desa & $\mathrm{x} 1$ & $\mathrm{x} 2$ & $\mathrm{x} 3$ & $\mathrm{x} 4$ & $\mathrm{x} 5$ & $x 6$ & $\mathrm{x} 7$ & $\ldots$ & $\mathrm{x} 12$ \\
\hline 3 & Pangkalan & 0.0439 & 0.0713 & 0.0305 & 0.0262 & 0.0058 & 0.1333 & 0.0000 & $\ldots$ & 0.0000 \\
\hline 6 & Air Buluh & 0.0968 & 0.0777 & 0.0125 & 0.0017 & 0.0029 & 0.3333 & 0.2857 & $\ldots$ & 0.0000 \\
\hline 7 & Lubuk Ramo & 0.0439 & 0.0331 & 0.0296 & 0.0195 & 0.0174 & 0.0000 & 0.0000 & $\ldots$ & 0.0000 \\
\hline 9 & Seberang Cengar & 0.0367 & 0.0522 & 0.0219 & 0.0128 & 0.0116 & 0.0667 & 0.0000 & $\ldots$ & 0.0000 \\
\hline$\ldots$ & $\ldots$ & $\ldots$ & $\ldots$ & $\ldots$ & $\ldots$ & $\ldots$ & $\ldots$ & $\ldots$ & $\ldots$ & $\ldots$ \\
\hline 1623 & Tebing Tinggi Okura & 0.0421 & 0.0433 & 0.0511 & 0.0306 & 0.0349 & 0.2667 & 0.1429 & $\ldots$ & 0.0000 \\
\hline
\end{tabular}


Tabel 11. Objek yang mendekati medoids 3

\begin{tabular}{clcccccccccc}
\hline No & \multicolumn{1}{c}{ Nama Desa } & $\mathrm{x} 1$ & $\mathrm{x} 2$ & $\mathrm{x} 3$ & $\mathrm{x} 4$ & $\mathrm{x} 5$ & $\mathrm{x} 6$ & $\mathrm{x} 7$ & $\ldots$ & $\mathrm{x} 12$ & \\
\hline 1 & Sungai Besar & 0.0457 & 0.1096 & 0.0421 & 0.0390 & 0.0494 & 0.2000 & 0.1429 & $\ldots$ & 0.0000 \\
57 & Muara Lembu & 0.1308 & 0.1516 & 0.0287 & 0.0273 & 0.0233 & 0.2667 & 0.4286 & $\ldots$ & 0.0000 \\
66 & Sungai Kuning & 0.1263 & 0.1006 & 0.0143 & 0.0161 & 0.0000 & 0.0000 & 0.0000 & $\ldots$ & 0.0000 \\
69 & Sungai Buluh & 0.1102 & 0.1210 & 0.0578 & 0.0356 & 0.0436 & 0.1333 & 0.1429 & $\ldots$ & 0.0000 & $\ldots$ \\
$\ldots$ & $\ldots$ & $\ldots$ & $\ldots$ & $\ldots$ & $\ldots$ & $\ldots$ & $\ldots$ & $\ldots$ & $\ldots$ & $\ldots$ & 0.0000 \\
1656 & Bintan & 0.0224 & 0.0178 & 0.0663 & 0.1324 & 0.4535 & 0.2667 & 0.1429 & \\
\hline
\end{tabular}

Tabel 12. Cluster 1 pada Algoritma K-Means

\begin{tabular}{clccccccccc}
\hline No & \multicolumn{1}{c}{ Desa } & $\mathrm{x} 1$ & $\mathrm{x} 2$ & $\mathrm{x} 3$ & $\mathrm{x} 4$ & $\mathrm{x} 5$ & $\mathrm{x} 6$ & $\mathrm{x} 7$ & $\ldots$ & $\mathrm{x} 12$ \\
\hline 232 & Bukit Meranti & 0.0260 & 0.0484 & 0.0363 & 0.0384 & 0.1860 & 0.2667 & 0.0000 & $\ldots$ & 0.0000 \\
252 & Aur Cina & 0.1057 & 0.1134 & 0.0305 & 0.0095 & 0.0233 & 0.4000 & 0.1429 & $\ldots$ & 0.0000 \\
430 & Pulau Kijang & 0.4337 & 0.2981 & 0.2360 & 0.2065 & 0.2820 & 0.3333 & 0.1429 & $\ldots$ & 0.0000 \\
481 & Sungai Perak & 0.1953 & 0.1618 & 0.1594 & 0.0729 & 0.0465 & 0.4667 & 1.0000 & $\ldots$ & 0.0000 \\
$\ldots$ & $\ldots$ & $\ldots$ & $\ldots$ & $\ldots$ & $\ldots$ & $\ldots$ & $\ldots$ & $\ldots$ & $\ldots$ & $\ldots$ \\
1656 & Bintan & 0.0224 & 0.0178 & 0.0663 & 0.1324 & 0.4535 & 0.2667 & 0.1429 & $\ldots$ & 0.0000 \\
\hline
\end{tabular}

Tabel 13. Cluster 2 pada Algoritma K-Means

\begin{tabular}{clccccccccc}
\hline No & \multicolumn{1}{c}{ Desa } & $\mathrm{x} 1$ & $\mathrm{x} 2$ & $\mathrm{x} 3$ & $\mathrm{x} 4$ & $\mathrm{x} 5$ & $\mathrm{x} 6$ & $\mathrm{x} 7$ & $\ldots$ & $\mathrm{x} 12$ \\
\hline 2 & IBUL & 0.0108 & 0.0255 & 0.0152 & 0.0189 & 0.0145 & 0.0000 & 0.0000 & $\ldots$ & 0.0000 \\
3 & PANGKALAN & 0.0439 & 0.0713 & 0.0305 & 0.0262 & 0.0058 & 0.1333 & 0.0000 & $\ldots$ & 0.0000 \\
4 & MUARA PETAI & 0.0314 & 0.0217 & 0.0157 & 0.0117 & 0.0116 & 0.0667 & 0.0000 & $\ldots$ & 0.0000 \\
5 & PANTAI & 0.0197 & 0.0382 & 0.0175 & 0.0078 & 0.0203 & 0.0000 & 0.0000 & $\ldots$ & 0.0000 \\
$\ldots$ & $\ldots$ & $\ldots$ & $\ldots$ & $\ldots$ & $\ldots$ & $\ldots$ & $\ldots$ & $\ldots$ & $\ldots$ & $\ldots$ \\
1653 & BULUH KASAP & 0.0099 & 0.0306 & 0.0394 & 0.1041 & 0.2849 & 0.0000 & 0.0000 & $\ldots$ & 0.0000 \\
\hline
\end{tabular}

Tabel 14. Cluster 3 pada Algoritma K-Means

\begin{tabular}{|c|c|c|c|c|c|c|c|c|c|c|}
\hline No & Desa & $\mathrm{x} 1$ & $\mathrm{x} 2$ & $\mathrm{x} 3$ & $\mathrm{x} 4$ & $\times 5$ & $\mathrm{x6}$ & $\mathrm{x} 7$ & $\ldots$ & $\mathrm{x} 12$ \\
\hline 1 & Sungai Besar & 0.0457 & 0.1096 & 0.0421 & 0.0390 & 0.0494 & 0.2000 & 0.1429 & & 0.0000 \\
\hline 28 & Perhentian Sungkai & 0.0206 & 0.0611 & 0.0309 & 0.0150 & 0.0087 & 0.1333 & 0.0000 & $\ldots$ & 0.0000 \\
\hline 6 & Air Buluh & 0.0968 & 0.0777 & 0.0125 & 0.0017 & 0.0029 & 0.3333 & 0.2857 & $\ldots$ & 0.0000 \\
\hline 31 & Sungai Kelelawar & 0.0242 & 0.0229 & 0.0090 & 0.0033 & 0.0087 & 0.0667 & 0.0000 & $\ldots$ & 0.0000 \\
\hline$\ldots$ & $\ldots$ & $\begin{array}{ll}\ldots \\
0.502\end{array}$ & $\ldots$ & $\ldots$ & $\ldots$ & $\ldots$ & $\ldots$ & $\ldots$ & $\ldots$ & $\ldots$ \\
\hline
\end{tabular}

Tabel 15. Hasil Validasi Silhoutte algoritma $K$-Medoids

\begin{tabular}{cccc}
\hline Cluster & Rata-rata Jarak pada Cluster & Rata-rata Jarak pada Luar Cluster & Silhoutte \\
\hline 1 & 0.053059 & 0.30076 & 0.823583 \\
2 & 0.075398 & 0.323903 & 0.76722 \\
3 & 0.171443 & 0.156363 & -0.08796 \\
\hline
\end{tabular}

Tabel 16. Hasil Validasi Silhoutte algoritma K-Means

\begin{tabular}{cccc}
\hline Cluster & Rata-rata Jarak pada Cluster & Rata-rata Jarak pada Luar Cluster & Silhoutte \\
\hline 1 & 0.6671 & 0.2245 & -0.6635 \\
3 & 0.1219 & 0.5279 & 0.7691 \\
\end{tabular}

\section{KESIMPULAN DAN SARAN}

K-Medoids mampu melakukan pengelompokan pada data sebaran anak cacat yang ada pada Provinsi Riau. Klaster yang dihasilkan pada penelitian ini adalah berjumlah tiga klaster. Klaster pertama mempunyai pola dengan jumlah penyandang Tuna Daksa, Tuna Netra, Tuna Rungu, Tuna Wicara, dan Cacat Mental masing-masing adalah 3, 2, 1, 2, dan 3. Hal ini menunjukkan bahwa pada klaster pertama memiliki data dengan nilai yang paling rendah dibandingkan klaster lainnya. Pada klaster kedua jumlah penyandang Tuna Daksa, Tuna Netra, Tuna Rungu, Tuna Wicara, dan Cacat Mental masing-masing adalah 7, 1, 3, 2, dan 3. Hal ini menunjukkan klaster kedua mempunyai data tingkat sebaran anak cacat yang lebih tinggi dibandingkan pada klaster yang pertama. Sedangkan pada klaster yang ketiga, Pola yang terbentuk pada klaster 3 adalah jumlah cacat (semua fisik) antara 015. Sementara jumlah penyandang Tuna Daksa, Tuna Netra, Tuna Rungu, Tuna Wicara, dan Cacat Mental masing-masing adalah 7, 5, 3, 4, dan 5. Hal ini menunjukkan klaster ketiga mempunya data dengan nilai cacat yang paling tinggi dibanding klaster lainnya. Adapun hasil validasi yang dihasilkan adalah 0.5009, ini menunjukkan bahwa AlgoritmaK-Medoids cukup baik dalam melakukan Pengelompokan pada data sebaran cacat pada Anak di wilayah Provinsi Riau.

Algoritma K-Medoids dan K-Means dibandingkan dengan melihat nilai validitasnya. Validitas yang digunakan pada penelitian ini adalah 
validitas Silhoutte Coefficient Adapun nilai validitas yang dihasilkan pada algoritma $K$-Medoids adalah sebesar 0.5009. Sedangkan nilai validitas yang dihasilkan pada algoritma K-Means adalah 0.1443 . Hal ini menunjukkan bahwa algoritma $K$-Medoids lebih baik dalam melakukan pengelompokan pada data sebaran Anak Cacat dibandingkan dengan algoritma $K$-Means.

\section{UCAPAN TERIMA KASIH}

Terima kasih yang sebesar-besarnya kepada Fakultas Sains dan Teknologi Universitas Islam Negeri Sultan Syarif Kasim Riau yang telah memberikan dukungan dan fasilitas dari pimpinan. Demikian juga ucapan terima kasih kepada Bapak Mustakim, S.T., M.Kom selaku dosen pembimbing matakuliah Data Mining, sehingga penelitian ini dapat diselesaikan dengan baik.

\section{REFERENSI}

[1] Fizdalifar, M. Gengki. Tingkat Kecemasan Sosial pada Anak yang Mengalami Cacat Fisik di YPAC. ISBN 978-979-796-324-8. 2015

[2] UU 4/1997, Penyandang cacat pada Bab 1 Pasal 1 ayat 1

[3] Republika.co.id,jum,at, 6 Desember 2017

[4] Dr. T. Velmurugan. Efficiency of k-Means and KMedoids Algorithms for Clustering Arbitrary Data Points. ISSN: 2229-6093. Vol 3. 2012

[5] Chrisnanto, Yulison Herry Dan Abdillah, Gunawan. Penerapan Algoritma Partitioning Around Medoids (PAM) Clustering untuk Melihat Gambaran Umum Kemampuan Akademik Mahasiswa. Seminar Nasional Teknologi Informasi dan Komunikasi 2015 (SENTIKA 2015). 28 Maret 2015

[6] UU 4/1997, Penyandang cacat pada Bab 1 Pasal 1 ayat 1

[7] Batra. Aishwarya. Analysis and Approach: K-Means and K-Medoids Data MiningAlgorithms. 5th IEEE International Conference on Advanced Computing \& Communication Technologies. 2011

[8] Prasmesti, Dyang Falila, Furqon, M. Tanzil, Dewi, Candra. Implementasi Metode K-Medoids Clustering untuk Pengelompokan Data Potensi Kebakaran Hutan/ Lahan Berdasarkan Persebaran Titik Panas (Hotspot). Jurnal Pengembangan Teknologi Informasi dan Ilmu Komputer. Vol. 1, No. 9, Juni 2017, hlm. 723-732

[9] Junaedi, Hartanto., Herman, Budianto, 2011. Data Transformation Pada Data Mining. Prosiding Konferensi nasional "Inovasi dalam Desain dan Teknologi”. IDeaTech 2011

[10] Kalpit G. Soni and Dr. Atul Patel. "Comparative Analysis of K-means and K-medoids Algorithm on IRIS Data". International Journal of Computational Intelligence Research ISSN 0973-1873 Volume 13, Number 5 (2017), pp. 899-906

[11] Prasmesti, Dyang Falila, Furqon, M. Tanzil, Dewi, Candra. Implementasi Metode $K$-Medoids Clustering untuk Pengelompokan Data Potensi Kebakaran
Hutan/ Lahan Berdasarkan Persebaran Titik Panas (Hotspot). Jurnal Pengembangan Teknologi Informasi dan Ilmu Komputer. Vol. 1, No. 9, Juni 2017, hlm. 723-732

[12] Mustakim. Pemetaan Digital dan Pengelompokan Lahan Hijau di Wilayah Provinsi Riau Berdasarkan Knowledge Discovery in Databases (KDD) dengan TeknikK-Means Mining. Seminar Nasional Teknologi Informasi, Komunikasi dan Industri (SNTIKI). Pekanbaru. 3 Oktober 2012.

[13] Mustakim. Pemetaan Digital dan Pengelompokan Lahan Hijau di Wilayah Provinsi Riau Berdasarkan Knowledge Discovery in Databases (KDD) dengan TeknikK-Means Mining. Seminar Nasional Teknologi Informasi, Komunikasi dan Industri (SNTIKI). Pekanbaru. 3 Oktober 2012.

[14] Aditya, Zuliar, Mustakim .Perbandingan Algoritma Clustering K-Means dan Fuzzy C Means pada Data Knowledge User Modelling. Seminar Nasional Teknologi Informasi, Komunikasi dan Industri (SNTIKI). Pekanbaru 19 Mei 2017

[15] Aditya, Zuliar, Mustakim .Perbandingan Algoritma Clustering K-Means dan Fuzzy C Means pada Data Knowledge User Modelling. Seminar Nasional Teknologi Informasi, Komunikasi dan Industri (SNTIKI). Pekanbaru 19 Mei 2017 